Tersedia online di: http://ejournal-balitbang.kkp.go.id/index.php/ma

\title{
PERFORMA BUDIDAYA UDANG WINDU (Penaeus monodon) PADA MUSIM KEMARAU DI TAMBAK KECAMATAN MARUSU KABUPATEN MAROS
}

\author{
Akhmad Mustafa*, Andi Indra Jaya Asaad, dan Dominggus Linthin \\ Balai Riset Perikanan Budidaya Air Payau dan Penyuluhan Perikanan \\ Jl. Makmur Dg. Sitakka No. 129, Maros 90512, Sulawesi Selatan
}

(Naskah diterima: 19 Maret 2021; Revisi final: 31 Mei 2021; Disetujui publikasi: 31 Mei 2021)

\begin{abstract}
ABSTRAK
Salah satu program dari Gubernur Sulawesi Selatan periode 2018-2023 adalah mengembalikan kejayaan udang windu di Sulawesi Selatan. Telah dilakukan kegiatan yang bertujuan mengetahui performa budidaya udang windu di tambak pembudidaya yang dilaksanakan pada musim kemarau tahun 2019 di Kecamatan Marusu Kabupaten Maros. Kegiatan budidaya udang windu teknologi tradisional plus dilaksanakan di tambak Dusun Kurilompo, Desa Nisombalia Kecamatan Marusu Kabupaten Maros. Sebanyak enam petak tambak pembudidaya ditebari tokolan udang windu dengan padat penebaran dari 10.000 sampai 30.000 ekor/ha. Setelah dipelihara selama 69 sampai 80 hari dilakukan panen dan selanjutnya dilakukan penentuan sintasan, bobot rata-rata, produksi udang windu, dan rasio konversi pakan (RKP). Data yang diperoleh dianalisis secara deskriptif. Hasil kegiatan menunjukkan bahwa kualitas air di tambak Kecamatan Marusu, Kabupaten Maros pada musim kemarau dicirikan dengan salinitas yang berkisar antara 36,63-69,40 ppt; suatu kondisi yang tidak optimal untuk budidaya udang windu. Pada saat panen didapatkan sintasan udang windu dari $27,57 \%$ sampai $66,67 \%$ bobot rata-rata dari 14,29-40,00 g/ekor; produksi dari 90,1 $800,0 \mathrm{~kg} / \mathrm{ha} / \mathrm{musim}$; dan RKP dari 0,54:1 sampai 2,10:1. Disimpulkan bahwa budidaya udang windu di tambak bersalinitas tinggi di daerah ini merupakan penyebab utama rendahnya sintasan, bobot rata-rata, produksi udang windu, dan RKP. Direkomendasikan bahwa perbaikan budidaya udang dengan menjaga tingkat salinitas dalam nilai optimal harus disosialisasikan kepada pembudidaya udang windu di daerah tersebut.
\end{abstract}

\section{KATA KUNCl: budidaya tambak; musim kemarau; udang windu; Kabupaten Maros}

ABSTRACT: Tiger shrimp (Penaeus monodon) culture performance during dry season in brackishwater pond of Marusu Subdistrict Maros District. By: Akhmad Mustafa, Andi Indra Jaya Asaad, and Dominggus Linthin

One of the main aquaculture development targeted by the South Sulawesi Province for the period 20182023 is to restore the glory of tiger shrimp farming in South Sulawesi. The recent study was carried out to uncover redevelopment opportunities of tiger shrimp culture and determine the performance of tiger shrimp culture in the farmers' ponds. The study was performed during the dry season in Marusu Subdistrict Maros District, in 2019. Traditional plus tiger shrimp farming activities were carried out in the ponds of Kurilompo Subvillage, Nisombalia Village, Marusu Subdistrict, Maros District. A total of six brackishwater ponds were stocked with tiger shrimp fingerling with stocking densities of 10,000-30,000 ind./ha. After being cultured for 69 to 80 days, the shrimp were harvested and measured their survival rate, average weight, production of tiger shrimp, and feed conversion ratio (FCR). The data obtained were analyzed with descriptive statistics. The results showed that water quality in brackishwater ponds of Marusu Subdstrict Maros District, in the dry season is characterized by salinity ranging from 36.63 to $69.40 \mathrm{ppt}$, a condition that is not optimal for tiger shrimp culture. At harvest, the survival rate, average weight, production, and FCR of the farmed average tiger shrimp were $27.57 \% 66.67 \%$ 14.29-40.00 g/ind., $90.1-800.0 \mathrm{~kg} / \mathrm{ha} / \mathrm{season}$,

\# Korespondensi: Balai Riset Perikanan Budidaya Air Payau dan

Penyuluhan Perikanan. Jl. Makmur Dg. Sitakka No. 129,

Maros 90512, Sulawesi Selatan, Indonesia

E-mail: akhmadmustafa@yahoo.com 
and $0.54: 1-2.10: 1$, respectively. It is concluded that the culture of tiger shrimp in the brackishwater ponds with high salinity in this area is the primary cause of poor survival rate, average weight, production of tiger shrimp, and FCR. It is recommended that culture shrimp improvement via maintaining salinity level within the optimal values has to be disseminated to the fish farmers in the area.

\section{KEYWORDS: brackishwater pond aquaculture; dry season; tiger shrimp; Maros District}

\section{PENDAHULUAN}

Provinsi Sulawesi Selatan tercatat dalam sejarah budidaya udang windu (Penaeus monodon) di tambak Indonesia, sebab budidaya udang windu di tambak mulai dilakukan pada tahun 1962 di salah satu kabupaten di Sulawesi Selatan yaitu Kabupaten Je'neponto dan baru pada tahun 1972 budidaya udang ini dilakukan di Pulau Jawa (Sianipar \& Genisa, 1987). Luas tambak di Sulawesi Selatan mencapai sekitar 107.500 ha yang digunakan untuk budidaya berbagai komoditas air payau seperti: udang windu, udang vaname, udang putih, udang apiapi, kepiting bakau, ikan bandeng, ikan kakap, ikan baronang, ikan mujair, ikan betok, ikan nila, dan rumput laut Gracilaria verrucosa (DKP, 2018). Pada tahun 1990-an produksi udang windu di Sulawesi Selatan mencapai puncaknya dan setelah itu terjadi penurunan produksi sebagai akibat serangan penyakit dan penurunan kualitas lingkungan tambak. Namun demikian, sampai tahun 2015, Sulawesi Selatan merupakan penghasil budidaya tambak terbesar di Indonesia, dan terbesar kedua khusus untuk udang windu (KKP, 2016). Khawatir produksi udang windu akan menurun, salah satu program dari Gubernur Sulawesi Selatan periode 20182023 adalah program kebangkitan udang windu di Sulawesi Selatan. Udang windu merupakan komoditas asli Indonesia yang menjadi komoditas primadona di tambak, termasuk tambak di Sulawesi Selatan. Udang windu adalah spesies pilihan karena laju pertumbuhannya yang tinggi, toleransi yang signifikan terhadap cekaman lingkungan, periode budidaya singkat, kemudahan dalam reproduksi, dan permintaan pasar yang tidak perlu dipertanyakan lagi (Shakir et al., 2014; Rahman et al., 2015). Program kebangkitan udang windu di Sulawesi Selatan diawali di 10 kabupaten yang memiliki lahan tambak, satu di antaranya di Kabupaten Maros. Sampai tahun 2019, Kabupaten Maros merupakan penghasil udang windu kedua tertinggi di Sulawesi Selatan, setelah Kabupaten Pinrang. Tambak di Kabupaten Maros mencapai luas 9.921,6 ha (BPS, 2019) yang tersebar di Kecamatan Bontoa, Lau, Maros Baru, Marusu, dan Bantimurung. Lokasi tambak untuk program kebangkitan udang windu di Sulawesi Selatan di Kabupaten Maros telah ditetapkan di Kecamatan Marusu dan Bontoa masingmasing seluas 5,0 ha. Teknologi yang diaplikasikan oleh pembudidaya tambak di Kecamatan Marusu untuk program kebangkitan udang windu di Sulawesi Selatan adalah teknologi tradisional plus. Produksi udang windu di Indonesia sebagian besar disumbangkan dari budidaya dengan teknologi tradisional dan tradisional plus, teknologi yang selaras dengan keberlanjutan, baik lingkungan maupun usaha.

Banyak faktor yang memengaruhi keberhasilan budidaya udang windu di tambak. Keberhasilan usaha budidaya udang windu di tambak pada umumnya ditentukan faktor manajemen. Faktor lainnya yang menentukan keberhasilan budidaya udang windu di tambak adalah faktor teknis seperti kualitas air (Mustafa, 2012; Anand et al., 2019). Kualitas air memainkan peran penting dalam meningkatkan produktivitas tambak udang windu. Air dapat menyediakan lingkungan yang seimbang dan sehat secara nutrisi bagi organisme yang dibudidayakan (Rahman et al., 2015).

Indonesia yang dikenal sebagai negara tropis memiliki dua musim yaitu kemarau dan hujan. Pada musim hujan terjadi kelimpahan air tawar yang menyebabkan terjadi pengenceran sehingga air mengalami penurunan salinitas, sebaliknya pada musim kemarau dengan intensitas radiasi matahari yang tinggi menyebabkan penguapan sehingga salinitas air menjadi tinggi. Hasil penelitian yang dilakukan oleh Ratnawati et al. (2020) di kawasan pesisir Kecamatan Suppa Kabupaten Pinrang Provinsi Sulawesi Selatan menunjukkan bahwa pada musim kemarau ditunjukkan dengan suhu, salinitas, $\mathrm{pH}$, dan nitrit yang lebih tinggi daripada musim hujan, sebaliknya oksigen terlarut, nitrogen amonia total, nitrat, dan fosfat yang lebih rendah daripada musim hujan. Telah dilaporkan pula oleh Mustafa et al. (2020) bahwa yang menjadi faktor pembatas untuk budidaya tambak pada musim kemarau di Kabupaten Maros adalah salinitas yang relatif tinggi. Dalam hal ini menunjukkan bahwa budidaya udang windu di tambak Kabupaten Maros pada musim kemarau merupakan kondisi yang tidak optimal. Kegiatan ini bertujuan untuk mengetahui performa budidaya udang windu di tambak pembudidaya pada musim kemarau di Kecamatan Marusu Kabupaten Maros Provinsi Sulawesi Selatan.

\section{BAHAN DAN METODE}

\section{Lokasi dan Waktu Kegiatan}

Lokasi tambak kegiatan terletak di Dusun Kurilompo Desa Nisombalia Kecamatan Marusu 
Kabupaten Maros Provinsi Sulawesi Selatan. Tata letak tambak terpilih di Kecamatan Marusu terlihat pada Gambar 1. Kegiatan dilaksanakan dari bulan Juli sampai Desember 2019 yang bertepatan dengan musim kemarau di Kabupaten Maros.

\section{Pelaksanaan Kegiatan}

\section{Karakterisasi Tanah Tambak}

Karakteristik tanah tambak diketahui dengan melakukan pengukuran dan pengambilan contoh tanah di tambak terpilih yang dilakukan sebelum persiapan tambak. Pengukuran dan pengambilan contoh tanah dilakukan pada kedalaman 0-20 cm dengan terlebih dahulu membuang endapan sedimen atau lumpur setebal 5-10 cm yang ada di permukaan tanah tambak. Kualitas tanah yang diukur di lapangan adalah $\mathrm{pH}_{\mathrm{F}}(\mathrm{pH}$ tanah yang diukur di lapangan) dengan $\mathrm{pH}$-meter dan $\mathrm{pH}_{\text {Fox }}(\mathrm{pH}$ tanah yang diukur di lapangan setelah dioksidasi dengan hidrogen peroksida $\left(\mathrm{H}_{2} \mathrm{O}_{2}\right) 30 \%$ dengan $\mathrm{pH}$-meter mengikuti petunjuk Ahern et al. (2004). Contoh tanah juga diambil untuk analisis peubah kualitas tanah lainnya di laboratorium. Pada setiap petak tambak dilakukan pengambilan satu contoh tanah pada saluran keliling tambak dan dua contoh tanah pada pelataran tambak dan selanjutnya dikomposit. Contoh tanah yang diambil secepatnya dimasukkan dalam kantong plastik dan selanjutnya dimasukkan dalam cool box yang diberi es. Penanganan contoh tanah dengan cara di-oven-kan pada suhu $80^{\circ} \mathrm{C}$ $85^{\circ} \mathrm{C}$ selama 48 jam (Ahern \& Blunden, 1998). Untuk mendapatkan ukuran partikel $0,5 \mathrm{~mm}$; maka contoh berukuran partikel 2,0 $\mathrm{mm}$ ditumbuk dan disaring dengan saringan $0,5 \mathrm{~mm}$. Kualitas tanah yang dianalisis di laboratorium meliputi bahan organik dari karbon organik (C organik) dengan metode Walkley \& Black, nitrogen total ( $\mathrm{N}$ total) dengan metode Kjeldahl, dan fosfat $\left(\mathrm{PO}_{4}\right)$ dengan metode Bray-1 mengikuti petunjuk Eviati \& Sulaeman (2009). Analisis kualitas tanah dilakukan di Laboratorium Tanah Balai Riset Perikanan Budidaya Air Payau dan Penyuluhan Perikanan (BRPBAP3), Maros.

\section{Persiapan Tambak}

Persiapan tambak dimulai dari perbaikan pintu air dan pematang, pemasangan saringan di pintu air, dan pengangkatan lumpur. Pengeringan dasar tambak dilakukan dengan mengeluarkan air secara gravitasi dan atau bantuan pompa air pada tambak yang sulit dikeringkan secara gravitasi. Tambak dibiarkan kering sampai dasar tambak retak-retak sedalam 1-2 cm atau yang berlangsung selama 1-2 minggu. Pemberantasan

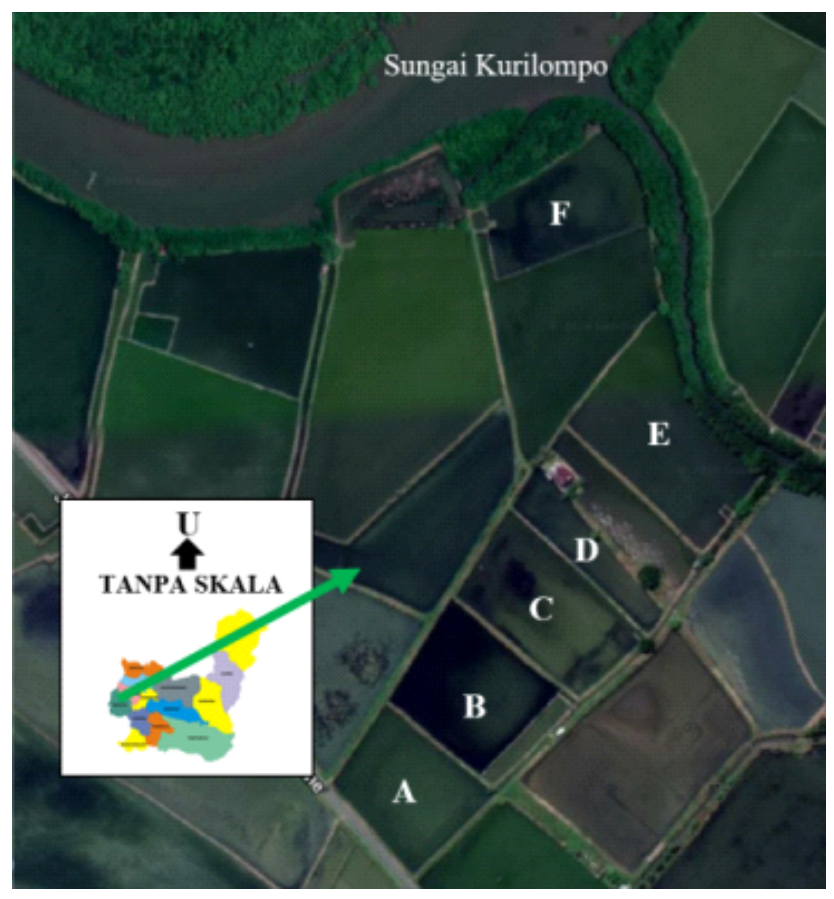

Gambar 1. Tata letak tambak untuk budidaya udang windu (Penaeus monodon) di tambak Kecamatan Marusu Kabupaten Maros Provinsi Sulawesi Selatan.

Figure 1. Layout of brackishwater ponds for tiger shrimp (Penaeus monodon) culture in ponds of Marusu Subdistrict, Maros District, South Sulawesi Province. 
hama menggunakan saponin dengan dosis $15 \mathrm{mg} / \mathrm{L}$ sebab salinitas air tambak lebih besar dari 20 ppt.

Dosis kapur bakar yang digunakan mengikuti petunjuk Mustafa et al. (2015) yang berdasarkan pada nilai $\Delta \mathrm{pH}\left(\mathrm{pH}_{\mathrm{F}}-\mathrm{pH}_{\mathrm{FOX}}\right)$ untuk meningkatkan $\mathrm{pH}$ tanah dan sebagai disinfektan. Pupuk diaplikasikan setelah 1-2 minggu setelah pengapuran. Pupuk organik yang digunakan adalah dedak yang dosisnya berdasarkan kandungan C-organik tanah yang ditebarkan merata pada dasar tambak untuk meningkatkan kandungan bahan organik tanah dan memperbaiki struktur tanah (Lampiran Tabel 1). Setelah 1-2 minggu sesudah pemberian pupuk organik, pupuk anorganik diaplikasikan sesuai tingkat kesuburan tanah yang mengacu pada petunjuk Davide (1976), Karthik et al. (2005), dan M ustafa et al. (2015). Teknik penumbuhan kelekap mengacu pada petunjuk M ustafa et al. (2015). Tambak diisi air sampai mencapai ketinggian air minimal 30-50 cm di pelataran tambak. Pupuk organik cair diaplikasikan untuk merangsang pertumbuhan pakan alami terutama plankton dan dibiarkan selama satu minggu. Tokolan udang windu dengan bo bot rata-rata 0,8 g/ekor yang merupakan hasil pentokolan dari pembudidaya tambak untuk selanjutnya ditebar di tambak pembesaran.

\section{Pemeliharaan Udang Windu}

Padat penebaran tokolan udang windu berkisar dari 10.000 sampai 30.000 ekor/ha seperti terlihat pada Tabel 1. Selama kegiatan budidaya udang windu dilakukan pergantian air pada saat pasang. Sumber air berasal dari Sungai Kurilompo, anak Sungai Maros (Gambar 1), yang sebelumnya air tambak dikeluarkan sekitar 20\%25\% Pemupukan susulan baik dengan pupuk Urea dan SP-36 dilakukan setiap dua minggu dengan dosis $10 \%$ dari dosis pemupukan awal (Lampiran Tabel 1). Pengapuran susulan dengan kapur dolomit dilakukan setiap empat minggu dengan dosis $5 \mathrm{mg} / \mathrm{L}$. Selama budidaya udang windu juga dilakukan pemberian probiotik RICA (probiotik produksi BRPBAP3) dengan dosis $10 \mathrm{mg} / \mathrm{L}$ yang diberikan setiap bulan. Kultur bakteri probiotik RICA dilakukan sesuai dengan petunjuk Susianingsih et al. (2012). Pemantauan kualitas air secara in situ dengan menggunakan alat ukur YSI Pro Plus dilakukan pada awal penebaran dan menjelang panen. Peubah kualitas air yang diukur meliputi: suhu, salinitas, $\mathrm{pH}$, dan oksigen terlarut. Pengukuran kualitas air dilakukan antara pukul 9.15 sampai dengan 10.00 WITA. Pemberian pakan tambahan dengan kandungan protein 30\%34\%dilakukan setelah udang windu berumur tujuh minggu sampai panen dengan dosis $2 \% 4 \%$ dari biomassa. Pemantauan kondisi udang windu dilakukan setiap dua minggu. Setelah dipelihara selama 69 hari sampai 80 hari di tambak pembesaran dilakukan panen total yang sebelumnya dilakukan panen parsial pada saat udang windu mulai berumur delapan minggu. Pada saat panen dilakukan penghitungan sintasan, bobot rata-rata, produksi udang windu, dan rasio konversi pakan (RKP).

\section{Analisis Data}

Data yang diperoleh dianalisis secara deskriptif yang meliputi rata-rata dan standar deviasi. Data disajikan dalam bentuk tabel. Data kualitas tanah hasil pengukuran maupun analisis di laboratorium yang diperoleh digunakan untuk penentuan dosis kapur dan dosis pupuk (Lampiran Tabel 1).

Tabel 1. Padat penebaran tokolan udang windu (Penaeus monodon) pada musim kemarau di tambak Kecamatan Marusu Kabupaten Maros Provinsi Sulawesi Selatan

Table 1. Stocking density of tiger shrimp (Penaeus monodon) fingerling during dry season in brackishwater ponds of Marusu Subdistrict, Maros District, South Sulawesi Province

\begin{tabular}{cccc}
\hline \multirow{2}{*}{$\begin{array}{c}\text { Tambak } \\
\text { Ponds }\end{array}$} & $\begin{array}{c}\text { Luas tambak } \\
\text { Ponds area } \\
\text { (ha) }\end{array}$ & \multicolumn{2}{c}{$\begin{array}{c}\text { Padat penebaran } \\
\text { Stocking density }\end{array}$} \\
\cline { 3 - 4 } & 0.70 & $\begin{array}{c}\text { Ekor/petak } \\
\text { Ind./pond }\end{array}$ & $\begin{array}{c}\text { Ekor/ha } \\
\text { Ind./ha }\end{array}$ \\
\hline A & 10,300 & 14,715 \\
B & 0.80 & 8,000 & 10,000 \\
C & 0.80 & 16,000 & 20,000 \\
D & 0.30 & 5,000 & 16,670 \\
E & 1.00 & 20,000 & 20,000 \\
F & 0.50 & 15,000 & 30,000 \\
\hline Total & 4.10 & 74,300 & 111,385 \\
\hline
\end{tabular}




\section{HASIL DAN BAHASAN}

\section{Kualitas Tanah}

Kualitas tanah merupakan peubah kunci pada budidaya udang windu teknologi tradisional dan tradisional plus, sebab ketersediaan makanan alami menjadi sangat penting untuk udang windu (Niraj \& Singh, 2014; Anand et al., 2019). Hasil pengukuran kualitas tanah tambak sebelum aplikasi kapur dan pupuk disajikan pada Tabel 2.

Hasil pengukuran $\mathrm{pH}_{\mathrm{F}}$ menunjukkan nilai dari 7,88 sampai 8,20; sedangkan $\mathrm{pH}_{\text {Fox }}$ menunjukkan nilai dari 2,39 sampai 5,64 di tambak Kecamatan Marusu (Tabel 2). Dari Tabel 2 menunjukkan bahwa $\Delta \mathrm{pH}$ relatif tinggi $(>4,50)$ dijumpai di tambak-C, D, E, dan $\mathrm{F}$ dan $\Delta \mathrm{pH}$ relatif rendah $(<3,00)$ di tambak-A dan $B$. Kondisi ini mengindikasikan bahwa tanah tambak di Kecamatan Marusu tergolong tanah sulfat masam. Hal ini juga menunjukkan bahwa potensi kemasaman tanah di tambak-C, D, E, dan $F$ yang lebih tinggi daripada tambak-A dan B. Dari Gambar 1 terlihat bahwa petak tambak-C, D, E, dan F lebih dekat dengan Sungai Kurilompo yang kemungkinannya lahan tambak tersebut adalah bekas lahan yang dahulu ditumbuhi mangrove, sehingga potensi kemasaman tanahnya lebih tinggi.

Bahan organik di tambak dapat berpengaruh terhadap kestabilan tanah, konsumsi oksigen, sumber unsur hara, dan kesesuaian habitat dari dasar tambak. Pada tanah yang mengandung liat yang tinggi ( $>60 \%$, kandungan bahan organik kurang dari $8,0 \%$ (C organik $<4,6 \%$ tergolong slight yaitu baik dan faktor pembatasnya mudah diatasi untuk budidaya tambak (Boyd, 1995), akan tetapi kandungan bahan organik yang sedikit lebih tinggi dibutuhkan untuk budidaya udang windu teknologi tradisional yang tidak membutuhkan pakan tambahan. Dari Tabel 2 terlihat bahwa kandungan C-organik tertinggi dijumpai di tambak-C yang kandungan C-organiknya mencapai $3,77 \%$ Di tambak ini juga dijumpai rasio C:N tertinggi di tanah tambak yang mencapai 62,83:1.

Kandungan $\mathrm{N}$ total tanah tambak berkisar antara $0,06 \%$ dan $0,09 \%$ dengan rata-rata $0,08 \%$ Menurut Davide (1976), kandungan $\mathrm{N}$ total tanah antara 0,16\% dan $0,20 \%$ tergolong cukup untuk budidaya tambak. Dengan demikian, tambak di Kecamatan Marusu tergolong rendah kandungan $\mathrm{N}$ totalnya. Rasio $\mathrm{C}: \mathrm{N}$ tanah tambak berkisar antara 36,75:1 dan 62,83:1 dengan rata-rata 42,91:1. Rasio $\mathrm{C}: \mathrm{N}$ tanah yang ideal untuk tambak adalah 8:1 sampai 12:1 (Boyd, 2008). Dari hasil ini menunjukkan bahwa tambak di Kecamatan Marusu tergolong memiliki rasio C:N tanah yang tinggi sehingga membutuhkan pupuk yang mengandung $\mathrm{N}$ seperti pupuk Urea yang lebih banyak, dan sebaliknya membutuhkan pupuk organik yang lebih sedikit untuk membuat tanah tambak lebih baik, yaitu rasio C:N tanah untuk mendekati 12:1.

Kandungan $\mathrm{PO}_{4}$ lebih besar dari $60 \mathrm{mg} / \mathrm{L}$ dalam tanah tambak dapat digolongkan sebagai slight atau tergolong baik dengan faktor pembatas yang sangat mudah diatasi (Karthik et al., 2005). Kandungan fosfat tanah tambak di Kecamatan Marusu sangat bervariasi yang berkisar antara 53,36 dan 204,95 mg/L dengan rata-rata $166,30 \pm 57,23 \mathrm{mg} / \mathrm{L}$. Secara umum, tingginya

Tabel 2. Kualitas tanah tambak pada budidaya udang windu (Penaeus monodon) di Kecamatan Marusu Kabupaten Maros Provinsi Sulawesi Selatan

Table 2. Soil quality of brackishwater pond for tiger shrimp (Penaeus monodon) culture in Marusu Subdistrict, Maros District, South Sulawesi Province

\begin{tabular}{|c|c|c|c|c|c|c|c|}
\hline $\begin{array}{l}\text { Tambak } \\
\text { Ponds }\end{array}$ & $\mathrm{pH}_{\mathrm{F}}$ & $\mathrm{pH}_{\mathrm{Fox}}$ & $\begin{array}{c}\Delta p H \\
\left(\mathrm{pH}_{\mathrm{F}}-\mathrm{pH}_{\mathrm{Fox}}\right)\end{array}$ & $\begin{array}{c}\text { Corganik } \\
\text { Organic C } \\
(\%)\end{array}$ & $\begin{array}{c}\text { N total } \\
\text { Total } N \\
(\%)\end{array}$ & $\begin{array}{c}\mathrm{PO}_{4} \\
(\mathrm{mg} / \mathrm{L})\end{array}$ & $\begin{array}{l}\text { Rasio C:N } \\
\text { C:N ratio }\end{array}$ \\
\hline A & 8.08 & 5.64 & 2.44 & 3.44 & 0.09 & 53.36 & 38.22 \\
\hline B & 8.20 & 5.38 & 2.82 & 2.94 & 0.08 & 204.95 & 36.75 \\
\hline C & 8.09 & 3.17 & 4.92 & 3.77 & 0.06 & 196.25 & 62.83 \\
\hline D & 8.04 & 3.44 & 4.60 & 3.37 & 0.09 & 184.81 & 37.44 \\
\hline$E$ & 7.91 & 2.39 & 5.52 & 3.52 & 0.09 & 162.53 & 39.11 \\
\hline $\mathrm{F}$ & 7.88 & 3.21 & 4.67 & 3.45 & 0.08 & 195.88 & 43.13 \\
\hline $\begin{array}{l}\text { Rata-rata } \\
\text { Average }\end{array}$ & 8.03 & 3.87 & 4.16 & 3.42 & 0.08 & 166.30 & 42.91 \\
\hline $\begin{array}{l}\text { Standar deviasi } \\
\text { Standard deviation }\end{array}$ & 0.12 & 1.32 & 1.24 & 0.27 & 0.01 & 57.23 & 10.01 \\
\hline
\end{tabular}


kandungan $\mathrm{PO}_{4}$ dalam tanah tambak, diduga sebagai akibat tambak yang tergolong tambak yang telah lama digunakan yang tentunya disertai dengan aplikasi pupuk yang mengandung $P$. Fosfor yang tidak hilang pada saat panen, sebagian besar dalam keadaan terikat di tanah dalam bentuk tidak tersedia untuk tanaman (Boyd, 1995). Tanah dasar tambak mengakumulasi fosfor total sebesar $67,8 \%$ dari yang masuk dalam tambak (Boyd et al., 2006).

\section{Kualitas Air}

Kualitas air merupakan faktor penentu keberhasilan budidaya udang windu di tambak. Kualitas air yang baik adalah jika dapat mendukung kehidupan udang windu dan pakan alami. Kualitas air yang baik inilah yang berusaha dipertahankan atau diminimalkan perubahannya selama budidaya udang windu (Mustafa et al., 2015). Namun demikian, kualitas air ini dapat berubah selama budidaya udang windu sebagai akibat faktor internal dan eksternal lingkungan tambak, sehingga upaya pengelolaan kualitas air yang tepat untuk mempertahankan kualitas air tetap baik. Pengelolaan kualitas air sangat penting dilakukan untuk mencegah terjadinya tekanan lingkungan pada udang yang dapat mempercepat terjadinya berbagai serangan penyakit. Kualitas air yang diperoleh selama budidaya udang windu di tambak disajikan pada Table 3 dan 4.

Suhu juga berpengaruh pada kondisi fisiologi udang windu. Suhu air yang terukur di tambak budidaya udang windu berkisar dari $29,0^{\circ} \mathrm{C}$ sampai $32,9^{\circ} \mathrm{C}$ dengan ratarata $30,7^{\circ} \mathrm{C}$ pada awal budidaya udang windu (Tabel 3 ) dan menjadi dari $29,2^{\circ} \mathrm{C}$ sampai $34,0^{\circ} \mathrm{C}$ dengan rata- rata $30,8^{\circ} \mathrm{C}$ pada akhir budidaya udang windu. Suhu air yang layak untuk budidaya udang windu berkisar antara $26^{\circ} \mathrm{C}$ dan $32^{\circ} \mathrm{C}$ dan optimalnya antara $29^{\circ} \mathrm{C}$ dan $30^{\circ} \mathrm{C}$ (Poernomo, 1988). Pada suhu kurang dari $23^{\circ} \mathrm{C}$ atau lebih dari $30^{\circ} \mathrm{C}$, udang windu akan mengalami penurunan pertumbuhan (Wyban et al., 1995).

Pengaruh langsung salinitas terhadap organisme akuatik adalah melalui efeknya terhadap kandungan dan tekanan osmotik cairan dalam tubuh organisme akuatik (Poxton, 2003). Keseimbangan garam dan air dalam jaringan adalah sangat penting untuk menjaga koordinasi di dalam fungsi fisiologis. Pada perairan pesisir, nilai salinitas sangat dipengaruhi oleh masukan air tawar dari sungai dan air hujan. Udang windu mampu menyesuaikan diri terhadap salinitas air antara 3 dan 45 ppt, namun untuk pertumbuhan optimal diperlukan salinitas air antara 15 dan 25 ppt (Poernomo, 1988). Udang windu adalah spesies yang sangat eurihalin (Allan \& Maguire, 1992) dan sangat dapat mengatur osmolalitas hemolimnya pada berbagai salinitas (Antony \& Vungurala, 2015). Dari Tabel 3 terlihat bahwa salinitas air di tambak berkisar 36,63 sampai 44,73 ppt dengan rata-rata 40,89 ppt pada awal budidaya udang windu dan meningkat menjadi berkisar 41,36 sampai 69,40 ppt dengan ratarata 53,48 ppt pada akhir budidaya udang windu (Tabel 4). Telah dilaporkan sebelumnya oleh Mustafa et al. (2020) bahwa salinitas air tambak di Kabupaten Maros berkisar antara 16,71 sampai 63,74 ppt dengan ratarata 36,77 ppt pada musim kemarau. Kondisi ini menunjukkan bahwa salinitas air di tambak budidaya udang windu relatif tinggi sebagai akibat kegiatan yang

Tabel 3. Kualitas air pada awal budidaya udang windu (Penaeus monodon) pada musim kemarau di tambak Kecamatan Marusu Kabupaten Maros Provinsi Sulawesi Selatan

Table 3. Water quality in the early of tiger shrimp (Penaeus monodon) culture during dry season in brackishwater ponds of Marusu Subdistrict , Maros District, South Sulawesi Province

\begin{tabular}{cccccc}
\hline $\begin{array}{c}\text { Tambak } \\
\text { Ponds }\end{array}$ & $\begin{array}{c}\text { Suhu } \\
\text { Temperature } \\
\text { ('C) }\end{array}$ & $\begin{array}{c}\text { Salinitas } \\
\text { Salinity } \\
\text { (ppt) }\end{array}$ & pH & $\begin{array}{c}\text { Oksigen terlarut } \\
\text { Dissolved oxygen } \\
\text { (mg/L) }\end{array}$ & $\begin{array}{c}\text { Kedalaman air } \\
\text { Water depth } \\
\text { (cm) }\end{array}$ \\
\hline A & 29.0 & 41.40 & 8.98 & 7.60 & 40 \\
B & 30.9 & 44.73 & 8.99 & 9.82 & 40 \\
C & 30.2 & 43.96 & 9.24 & 9.34 & 40 \\
D & 32.9 & 40.78 & 9.16 & 11.90 & 30 \\
E & 30.3 & 37.84 & 8.91 & 11.77 & 30 \\
F & 30.7 & 36.63 & 8.71 & 6.89 & 50 \\
\hline Rata-rata & 30.7 & 40.89 & 9.00 & 9.54 & 38 \\
Average & & & & & \\
\hline Standar deviasi & 1.5 & 3.22 & 0.19 & 2.07 & 8 \\
Standard deviation & & & & &
\end{tabular}


Tabel 4. Kualitas air pada akhir budidaya udang windu (Penaeus monodon) pada musim kemarau di tambak Kecamatan Marusu Kabupaten Maros Provinsi Sulawesi Selatan

Table 4. Water quality in the end of tiger shrimp (Penaeus monodon) culture during dry season in brackishwater ponds of Marusu Subdistrict, Maros District, South Sulawesi Province

\begin{tabular}{cccccc}
\hline $\begin{array}{c}\text { Tambak } \\
\text { Ponds }\end{array}$ & $\begin{array}{c}\text { Suhu } \\
\text { Temperature } \\
\text { ('C) }\end{array}$ & $\begin{array}{c}\text { Salinitas } \\
\text { Salinity } \\
\text { (ppt) }\end{array}$ & pH & $\begin{array}{c}\text { Oksigen terlarut } \\
\text { Dissolved oxygen } \\
\text { (mg/L) }\end{array}$ & $\begin{array}{c}\text { Kedalaman air } \\
\text { Water depth } \\
\text { (cm) }\end{array}$ \\
\hline A & 29.2 & 53.40 & 8.30 & 2.27 & 40 \\
B & 29.8 & 69.40 & 8.85 & 3.99 & 50 \\
C & 34.0 & 68.48 & 9.10 & 3.96 & 50 \\
D & 29.6 & 44.66 & 8.58 & 2.86 & 40 \\
E & 31.5 & 43.58 & 8.55 & 3.02 & 50 \\
F & 30.7 & 41.36 & 8.33 & 2.65 & 70 \\
\hline Rata-rata & 30.8 & 53.48 & 8.61 & 3.12 & 50 \\
Average & 1.8 & 12.66 & 0.31 & 0.70 & 11 \\
\hline Standar deviasi & & & & \\
Standard deviation & & &
\end{tabular}

dilaksanakan ini termasuk pada musim kemarau. Mungkin ini pula yang menyebabkan pertumbuhan dan penghidupan dan akhirnya produksi udang windu yang lebih baik dijumpai di tambak-F (Tabel 5), sebab salinitas air berkisar 36,63 sampai 41,46 ppt; suatu kondisi salinitas yang lebih baik dari tambak lainnya. Udang windu akan berusaha menyesuaikan antara tekanan osmosis tubuhnya dengan kondisi lingkungannya. Penyesuaian ini memerlukan energi yang besar, sehingga energi yang diperoleh dari pakan digunakan untuk penyesuaian tersebut. Beberapa fakta menunjukkan bahwa energi (protein) yang lebih tinggi dibutuhkan pada kondisi salinitas lingkungan yang lebih tinggi (De Silva \& Perera, 1976). M enurut Woo \& Kelly (1995), pertumbuhan yang optimal pada organisme akuatik dicapai pada kondisi salinitas isoosmosis yang tidak memerlukan energi yang besar untuk proses osmoregulasi sehingga energi yang digunakan untuk pertumbuhan lebih banyak.

Derajat kemasaman atau $\mathrm{pH}$ adalah logaritma negatif dari aktivitas ion hidrogen (Boyd, 1990). Batas toleransi organisme akuatik terhadap $\mathrm{pH}$ bervariasi dan dipengaruhi oleh banyak faktor, antara lain: suhu, oksigen terlarut, alkalinitas, dan adanya anion dan kation, serta jenis dan stadium organisme. Walaupun tambak yang digunakan tergolong tanah sulfat masam, tetapi aplikasi kapur yang disesuaikan dengan kebutuhan kapur menyebabkan $\mathrm{pH}$ air tambak lebih besar dari 8,0. Pada awal budidaya udang windu, $\mathrm{pH}$ air berkisar dari 8,71 sampai 9,24 dengan rata-rata 9,00 (Tabel 4) dan berkisar dari 8,33 sampai 9,10 dengan rata-rata 8,62 pada akhir budidaya udang windu (Tabel 4). Kondisi pH air ini cukup mendukung pertumbuhan dan penghidupan udang windu di tambak. Kisaran $\mathrm{pH}$ yang baik untuk udang windu antara 7,5 dan 8,7 dengan optimal antara 8,0 dan 8,5 (Poernomo, 1988). Nilai pH antara 6,5 dan 8,5 diperlukan untuk mempertahankan produktivitas air dan fisiologi normal kehidupan organisme akuatik (Rahman et al., 2015).

Oksigen terlarut adalah jumlah oksigen terlarut dalam air yang berasal dari fotosintesis dan absorpsi atmosfer/udara. Oksigen terlarut yang diukur pada awal budidaya udang windu berkisar 6,89 sampai $11,90 \mathrm{mg} /$ $\mathrm{L}$ dengan rata-rata $9,55 \mathrm{mg} / \mathrm{L}$ (Tabel 3 ) dan menurun menjadi antara 2,27 dan 3,99 mg/L dengan rata-rata $3,12 \mathrm{mg} / \mathrm{L}$ pada akhir budidaya udang windu (Tabel 4). Ada beberapa petak tambak yang kandungan oksigen terlarutnya lebih rendah dari 3,0 mg/L; suatu kondisi yang cukup kritis untuk budidaya udang windu di tambak. Menurut Sukenda et al. (2006), bahwa turunnya nilai oksigen terlarut dipengaruhi oleh meningkatnya proses-proses mikroba yang terjadi pada akhir budidaya udang windu. Pada tambak-F, rendahnya kandungan oksigen terlarut diduga sebagai akibat cukup besar biomassa udang windu yang mengonsumsi oksigen terlarut.

\section{Produksi Udang Windu}

Padat penebaran udang windu adalah salah satu faktor teknis budidaya penting yang secara langsung memengaruhi sintasan, pertumbuhan, perilaku, kesehatan, makan, produksi, dan keuntungan (Shakir et al., 2014; Anand et al., 2019). Akibat perbedaan udang windu mencapai ukuran konsumsi dari setiap tambak, maka dilakukan panen pada umur udang windu 
yang berbeda pula. Panen dilakukan setelah udang windu dipelihara selama 69 sampai 80 hari dengan rata-rata 75 hari dan didapatkan produksi dari 90,1 sampai $800,0 \mathrm{~kg} / \mathrm{ha} / \mathrm{musim}$ dengan rata-rata $245,0 \mathrm{~kg} /$ ha/musim (Tabel 5). Produksi udang windu tertinggi dijumpai di tambak-F yaitu $800,0 \mathrm{~kg} / \mathrm{ha} /$ musim diduga sebagai akibat kualitas air, terutama salinitas yang lebih baik dibandingkan dengan tambak lainnya selama budidaya udang windu di tambak yaitu 36,63 ppt (Tabel 3) pada awal budidaya dan 41,36 ppt (Tabel 4) pada akhir budidaya. Letak tambak-F yang dekat dengan sumber air (Gambar 1) menjadi penyebab lebih baiknya kualitas air sebab pergantian air dengan air yang berkualitas baik lebih mudah dilakukan dibandingkan dengan tambak lainnya. RKP terendah yaitu 0,54:1 juga diperoleh pada tambak-F (Tabel 5) yang menunjukkan bahwa kualitas air cukup mendukung budidaya udang windu sehingga udang windu sangat efisien menggunakan pakan. Kualitas air yang buruk secara langsung memengaruhi nafsu makan udang windu, yang mengakibatkan berkurangnya fungsi pencernaan usus dan berkurangnya pencernaan nutrisi di usus sehingga meningkatkan RKP. Seperti dikatakan oleh Chaikaew et al. (2019) bahwa RKP dipengaruhi oleh kualitas air dan pengelolaan pakan pada budidaya udang. Selanjutnya Huet \& Timmermans (1994) menyatakan bahwa RKP juga dipengaruhi oleh sintasan, kepadatan, bo bot individu, perbedaan persentase makanan harian, waktu, dan lokasi budidaya, serta pertumbuhan biomassa udang. Oleh karena teknologi yang diaplikasikan pada kegiatan ini adalah teknologi tradisional plus, di mana pakan tambahan diberikan menjelang panen, sehingga diperoleh RKP yang tergolong rendah yaitu secara umum 0,90:1 (dengan menggunakan pakan tambahan sebesar $815,0 \mathrm{~kg}$ diproduksi udang windu sebesar $900,9 \mathrm{~kg}$ ).

Sintasan udang windu yang diperoleh bervariasi dari $27,57 \%$ sampai $66,67 \%$ dengan rata-rata $48,76 \%$ Pada padat penebaran udang windu 20.000 ekor/ha dengan lama pemeliharaan 112 hari pada musim kemarau di tambak pembudidaya di Kecamatan Suppa Kabupaten Pinrang Provinsi Sulawesi Selatan diperoleh sintasan sebesar 14,88\%(Rangka \& Mangampa, 2012). Cukup tingginya sintasan yang diperoleh pada kegiatan ini di antaranya sebagai akibat penggunaan tokolan udang windu. Selama produksi tokolan udang windu terjadi proses seleksi alami, dalam hal ini benur windu yang lemah akan mengalami kematian (Mustafa et al., 2015). Dengan demikian, tokolan udang windu dapat memiliki vitalitas yang baik yang berdampak pada sintasan yang cukup tinggi.

Bobot rata-rata udang windu berkisar dari 14,29 sampai 40,00 g/ekor dengan rata-rata 22,89 g/ekor. Dengan lama pemeliharaan rata-rata 75 hari ini menunjukkan bahwa bobot rata-rata udang windu ini relatif tinggi jika dibandingkan dengan yang dilaporkan sebelumnya. Dengan lama pemeliharaan 112 hari pada musim kemarau di tambak pembudidaya pada padat penebaran tokolan udang windu 20.000 ekor/ha di Kecamatan Suppa Kabupaten Pinrang diperoleh bobot rata-rata 24,43 g/ekor (Rangka \& Mangampa, 2012).

Tabel 5. Performa budidaya udang windu (Penaeus monodon) pada musim kemarau di tambak Kecamatan Marusu Kabupaten Maros Provinsi Sulawesi Selatan

Table 5. Tiger shrimp (Penaeus monodon) culture performance during dry season in brackishwater pond of Marusu Subdistrict, Maros District, South Sulawesi Province

\begin{tabular}{|c|c|c|c|c|c|c|c|}
\hline \multirow{2}{*}{$\begin{array}{l}\text { Tambak } \\
\text { Ponds }\end{array}$} & \multirow{2}{*}{$\begin{array}{c}\text { Luas } \\
\text { tambak } \\
\text { Ponds } \\
\text { area } \\
\text { (ha) }\end{array}$} & \multirow{2}{*}{$\begin{array}{l}\text { Lama pemeliharaan } \\
\text { (hari) } \\
\text { Culture duration } \\
\text { (days) }\end{array}$} & \multirow{2}{*}{$\begin{array}{l}\text { Sintasan } \\
\text { Survival } \\
\text { rate } \\
\%\end{array}$} & \multirow{2}{*}{$\begin{array}{c}\text { Bobot rata-rata } \\
\text { (g/ekor) } \\
\text { Average weight } \\
\text { (g/ind.) }\end{array}$} & \multicolumn{2}{|c|}{$\begin{array}{c}\text { Produksi } \\
\text { Production }\end{array}$} & \multirow{2}{*}{$\begin{array}{c}\text { Rasio konversi } \\
\text { pakan } \\
\text { Food conversion } \\
\text { ratio }\end{array}$} \\
\hline & & & & & $\begin{array}{l}\mathrm{kg} / \text { petak } \\
\mathrm{kg} / \text { pond }\end{array}$ & $\mathrm{kg} / \mathrm{ha}$ & \\
\hline A & 0.70 & 71 & 27.57 & 22.22 & 63.1 & 90.1 & $0.95: 1$ \\
\hline B & 0.80 & 69 & 62.44 & 22.22 & 111.0 & 138.8 & $0.90: 1$ \\
\hline C & 0.80 & 72 & 34.91 & 22.22 & 124.1 & 155.1 & $1.33: 1$ \\
\hline D & 0.30 & 80 & 49.98 & 14.29 & 35.7 & 119.0 & $2.10: 1$ \\
\hline E & 1.00 & 80 & 51.00 & 16.39 & 167.0 & 167.0 & $1.20: 1$ \\
\hline $\mathrm{F}$ & 0.50 & 79 & 66.67 & 40.00 & 400.0 & 800.0 & $0.54: 1$ \\
\hline $\begin{array}{l}\text { Rata-rata } \\
\text { Average }\end{array}$ & & 75 & 48.76 & 22.89 & & 245.0 & \\
\hline $\begin{array}{c}\text { Standar deviasi } \\
\text { Standard deviation }\end{array}$ & & 5 & 15.20 & 9.06 & & 273.3 & \\
\hline Total & 4.1 & & & & 900.9 & & \\
\hline
\end{tabular}


Hal ini sebagai akibat lebih cepatnya pertumbuhan udang windu yang telah ditokolkan sebelumnya, karena udang windu dapat mengambil keuntungan dari kapasitas pertumbuhan kompensasi (compensatory growth capacity) yang dimilikinya (Mustafa \& Mangampa, 1990; Mustafa et al., 2015; Surendran et al., 2019). Pertumbuhan udang windu yang lambat pada saat pentokolan karena dipelihara dalam padat penebaran sangat tinggi dan akan memperoleh pertumbuhan kompensasi berupa pertumbuhan yang cepat pada saat mendapatkan kondisi lebih optimal di tambak. Selain penggunaan tokolan, pengelolaan air yang relatif baik berupa pergantian air dan penggunaan probiotik RICA juga diduga menjadi penyebab lain cukup tingginya produksi udang windu yang dicirikan dengan sintasan yang cukup tinggi dan bobot udang windu yang juga cukup tinggi, walaupun dilakukan pada musim kemarau yang bukan merupakan kondisi optimal untuk budidaya udang windu. Manajemen kualitas air penting dalam budidaya udang windu (Rahman et al., 2015). Dengan demikian, melalui persiapan tambak yang tepat termasuk aplikasi kapur dan pupuk yang disesuaikan dengan karakteristik tanah tambak, penggunaan tokolan udang windu yang disertai dengan pengelolaan air yang baik walaupun dilaksanakan pada musim kemarau dengan kondisi yang tidak optimal dapat diproduksi udang windu dengan hasil yang cukup memuaskan pada tambak tertentu. Hal ini juga menunjukkan bahwa prospek budidaya udang di tambak Kabupaten Maros cukup menjanjikan, apalagi jika dilaksanakan pada musim yang lebih baik yang dicirikan dengan kondisi kualitas air yang lebih baik pula.

\section{KESIMPULAN DAN SARAN}

Budidaya udang windu di tambak Kecamatan Marusu Kabupaten Maros pada musim kemarau masih dapat dilakukan, walaupun tidak optimal karena salinitas air tambak berkisar antara 36,63 dan 69,40 ppt. Produksi tertinggi diperoleh pada tambak yang selama budidaya udang windu memiliki salinitas air yang relatif lebih rendah. Pengelolaan tanah yang disesuaikan dengan karakteristik tanah, pengelolaan air melalui pergantian air yang lebih banyak, dan penggunaan tokolan udang windu meningkatkan performa budidaya udang windu di tambak pada musim kemarau. Oleh karena itu, disarankan agar kegiatan yang sama di masa mendatang di Kabupaten Maros agar dilaksanakan pada kondisi salinitas yang lebih baik untuk pertumbuhan dan penghidupan udang windu di tambak.

\section{UCAPAN TERIMA KASIH}

Diucapkan terima kasih kepada Tenaga Teknis Perikanan Budidaya Lingkup Dinas Perikanan
Kabupaten Maros tahun 2019 atas bantuan selama pelaksanaan kegiatan ini. Terima kasih juga diucapkan kepada para pembudidaya tambak dari Kelompok Pembudidaya Ikan Taroada yang terlibat dalam kegiatan ini. Kegiatan ini didanai oleh Dinas Kelautan dan Perikanan Provinsi Sulawesi Selatan pada Tahun Anggaran 2019. Sebagai kontributor utama dari karya tulis ilmiah ini adalah Akhmad Mustafa, sedangkan sebagai kontributor anggota adalah Andi Indra Jaya Asaad dan Dominggus Linthin.

\section{DAFTAR ACUAN}

Ahern, C.R. \& Blunden, B. (1998). Designing a soil sampling and analysis program. In Ahern, C.R., Blunden, B., \& Stone, Y. (Eds.). Acid Sulfate Soils Laboratory Methods Guidelines (p. 2.1-2.6). Wollongbar, NSW: Acid Sulfate Soil Management Advisory Committee.

Ahern, C.R., Blunden, B., Sullivan, L.A., \& McElnea, A. E. (2004). Soil sampling, handling, preparation and storage for analysis of dried samples. In Acid Sulfate Soils Laboratory Methods Guidelines ( $p$. B1-1"B1-5). Indooroopilly, Queensland: Queensland Department of Natural Resources, Mines and Energy.

Allan, G.L. \& Maguire, G.B. (1992). Effect of pH and salinity on survival, growth and osmoregulation in Penaeus monodon Fabricius. Aquaculture, 107, 33-47. https://doi.org/10.1016/00448486(92)90048-P.

Anand, P.S.S., Balasubramanian, C.P., Christina, L., Kumar, S., Biswas, G., De, D., ... \& \& Vijayan, K.K. (2019). Substrate based black tiger shrimp, Penaeus monodon culture: Stocking density, aeration and their effect on growth performance, water quality and periphyton development. Aquaculture, 507, 411-418. https://doi.org/10.1016/ j.aquaculture.2019.04.031.

Antony, J. \& Vungurala, H. (2015). Effects of salinity and $\mathrm{Na}^{+} / \mathrm{K}^{+}$ratio on osmoregulation and growth performance of black tiger prawn, Penaeus monodon Fabricius, 1798, juveniles reared in inland saline water. Journal of the World Aquaculture Society, 46(2), 171-182. https://doi.org/ 10.1111/jwas.12179.

Badan Pusat Statistik [BPS]. (2019). Provinsi Sulawesi Selatan dalam Angka 2019. Makassar: Badan Pusat Statistik Provinsi Sulawesi Selatan, $504 \mathrm{hlm}$.

Boyd, C.E. (1990). Water quality in ponds for aquaculture. Alabama: Agriculture Experiment Station, Auburn University, 482 pp. 
Boyd, C.E. (1995). Bottom soils, sediment, and pond aquaculture. New York: Chapman and Hall, 348 pp.

Boyd, C.E. (2008). Pond bottom soil analyses. Global Aquaculture Advocate, September/October, p. 91-92.

Boyd, C.E., Corpron, K., Bernard, E., \& Pengsang, P. (2006). Estimates of bottom soil and effluent load of phosphorus at a semi-intensive marine shrimp farm. Journal of World Aquaculture Society, 37(1), 41-47. $\quad$ https://doi.org/10.1111/j.17497345.2006.00005.x.

Chaikaew, P., Rugkarn, N., Pongpipatwattana, V., \& Kanokkantapong, V. (2019). Enhancing ecologicaleconomic efficiency of intensive shrimp farm through in-out nutrient budget and feed conversion ratio. Sustainable Environment Research, 29(28), 1-11. https://doi.org/10.1186/s42834-0190029-0.

Davide, J.G. (1976). Fish pond soil and fertilizers. In Lopez, A.M. (Ed.). Pond Construction and Management. Iloilo City: Western Visayas Federation of Fish Producers, Inc., p. 1-6.

De Silva, S.S. \& Perera, P.A.B. (1976). Studies on the young grey mullet, Mugil cephalus L.: I. Effects of salinity on food intake, growth and food conversion. Aquaculture, 7, 327-338. https://doi.org/ 10.1016/0044-8486(76)90129-0.

Dinas Kelautan dan Perikanan [DKP]. (2018). Laporan statistik perikanan Sulawesi Selatan 2017. Makassar: Dinas Kelautan dan Perikanan Provinsi Sulawesi Selatan, $165 \mathrm{hlm}$.

Eviati \& Sulaeman. (2009). Analisis kimia tanah, tanaman, air, dan pupuk. Petunjuk Teknis (Edisi 2). Bogor: Balai Penelitian Tanah, $234 \mathrm{hlm}$.

Huet, M. \& Timmermans, J. (1994). Textbook of fish culture: Breeding and cultivation of fish. London: John Wiley and Sons Ltd., 456 pp.

Karthik, M., Suri, J., Saharan, N., \& Biradar, R.S. (2005). Brackish water aquaculture site selection in Palghar Taluk, Thane District of Maharashtra, India, using the techniques of remote sensing and geographical information system. Aquacultural Engineering, 32, 285-302. https://doi.org/10.1016/ j.aquaeng.2004.05.009.

Kementerian Kelautan dan Perikanan [KKP]. (2016). Peta sentra produksi perikanan budidaya. Jakarta: Kementerian Kelautan dan Perikanan, $57 \mathrm{hlm}$.

Mustafa, A. (2012). Kriteria kesesuaian lahan untuk berbagai komoditas di tambak. Media Akuakultur,
7(2), 108-118. https://doi.org/10.15578/ ma.7.2.2012.108-118.

Mustafa, A., Asaad, A.I.J., \& Rimmer, M.A. (2020). Land characteristics and suitability for tilapia culture at different seasons in brackishwater ponds of Bontoa Subdistrict, Maros Regency, Indonesia. IOP Conference Series: Earth and Environmental Science, 473(012072), 12 pp. https://doi.org/10.1088/ 1755-1315/473/1/012072.

Mustafa, A. \& Mangampa, M. (1990). Usaha budidaya udang tambak menggunakan benur windu, Penaeus monodon yang berbeda lama pembantutannya. Jurnal Penelitian Budidaya Pantai, 6(2), 35-48.

Mustafa, A., Mangampa, M., \& Ratnawati, E. (2015). Panen untung dari produksi udang dalam waktu singkat. Yogyakarta: Andi Offset, $178 \mathrm{hlm}$.

Niraj, K. \& Singh, N.P. (2014). Chemical parameters of soil of Turkaulia Lake of North Bihar (India) in relation to its productivity. International Research Journal of Environmental Sciences, 3(3), 1-4.

Poernomo, A. (1988). Pembuatan tambak udang di Indonesia. Seri Pengembangan No. 7. Maros: Balai Penelitian Perikanan Budidaya Pantai, $40 \mathrm{hlm}$.

Poxton, M. (2003). Water quality. In Lucas, J.S. \& Southgate, P.C. (Eds.). Aquaculture: Farming aquatic animals and plants. Oxford: Blackwell Publishing Ltd., p. 47-73.

Rahman, Md. Z., Zaman, Md.F.U., Khondoker, S., Hasan-Uj-Jaman, Md., Hossain, Md.L., Banerjee, S., \& Bappa, S.B. (2015). Water quality assessment of a shrimp farm: A study in a salinity prone area of Bangladesh. International Journal of Fisheries and Aquatic Studies, 2(5), 9-19.

Rangka, N.A. \& Mangampa, M. (2012). Pengaruh pergiliran bakteri probiotik terhadap sintasan dan produksi udang windu di tambak tradisional di Kecamatan Suppa Kabupaten Pinrang. Dalam Prosiding Seminar Nasional Tahunan IX Hasil Penelitian Perikanan dan Kelautan. Yogyakarta: Universitas Gadjah Mada, hlm. RB15.1-RB15.9.

Ratnawati, E., Mustafa, A., \& Tarunamulia. (2020). Keragaan panti benih udang skala kecil dan besar di Kecamatan Suppa Kabupaten Pinrang. Media Akuakultur, 15(2), 79-88. https://doi.org/10.15578/ ma.15.2.2020.79-88.

Shakir, C., Lipton, A.P., Manilal, A., Sugathan, S., \& Selvin, J. (2014). Effect of stocking density on the survival rate and growth performance in Penaeus 
monodon. Journal of Basic \& Applied Sciences, 10, 231-238. https://doi.org/10.6000/19275129.2014.10.32.

Sianipar, P. \& Genisa, A.S. (1987). Sejarah dan tipe budidaya udang. Oseana, XII(1), 35-41.

Sukenda, Hadi, P., \& Harris, E. (2006). Pengaruh pemberian sukrosa sebagai sumber karbon dan probiotik terhadap dinamika populasi bakteri dan kualitas air media budidaya udang vaname, Litopenaeus vannamei. Jurnal Akuakultur Indonesia, 5(2), 179-190.

Surendran, V., Ravikumar, Y., Chandrashekhar, J.Y.R., \& Anantheswara, B.D. (2019). Experiences at a farm-based, pond-type Litopenaeus vannamei nursery in India. AQUA Culture Asia Pasific, 15(5), 8-14.
Susianingsih, E., Nurbaya, \& Atmomarsono, M. (2012). Pengaruh kombinasi jenis bakteri probiotik berbeda terhadap sintasan dan produksi udang windu di tambak semi-intensif. Jurnal Riset Akuakultur, 7(3), 485-498. https://doi.org/10.15578/ jra.7.3.2012.485-498.

Woo, N.Y.S. \& Kelly, S.P. (1995). Effects of salinity and nutritional status on growth and metabolism of Sparus sarba in a closed seawater system. Aquaculture, 135, 229-238.

Wyban, J., Walsh, W.A., \& Godin, D.M. (1995). Temperature effects on growth, feeding rate and feed conversion of the Pacific white shrimp (Penaeus vannamei). Aquaculture, 138(1-4), 267-279. 


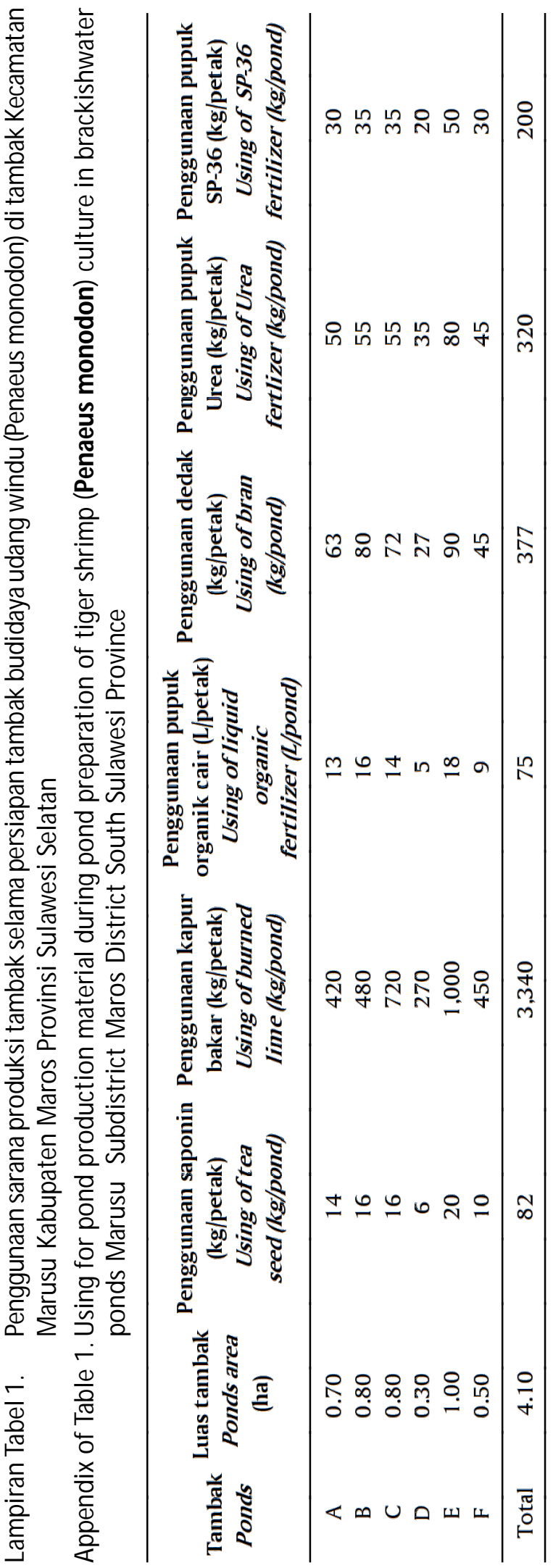

